13. Reddy, A., Profitability and labour use in cropping systems Indian J. Dryland Agric. Res. Dev., 2014, 29(1), 97-106.

14. Pant, J., Demaine, H. and Edwards, P., Bio-resource flow in integrated agriculture-aquaculture systems in a tropical monsoonal climate: a case study in northwest Thailand. Agric. Syst., 2005, 83, 203-219.

15. Shekinah, D. E., Jayanthi, C. and Sankaran, N., Physical indicators of sustainability - a farming systems approach for the small farmer in the rain-fed vertisols of western zone of Tamil Nadu. J. Sustain. Agric., 2005, 25, 43-65.

16. Devendra, C., Animal production and rainfed agriculture in Asia: potential opportunities for productivity enhancement. Outlook Agric., 2000, 29(3), 161-175.

17. Parthasarathy, R. P. and Hall, A. J., Importance of crop residues in crop-livestock systems in India and farmers' perceptions of fodder quality in coarse cereals. Field Crops Res., 2003, 84, 189-198.

18. Khan, S. A., Malav, L. C., Kumar, S., Malav, K. and Gupta, N., Resource utilization of biogas slurry for better yield and nutritional quality of baby corn. Adv. Environ. Agric. Sci., 2016, 382-394.

19. Behera, U. K. and Mahapatra, I. C., Income and employment generation for small and marginal farmers through integrated farming systems. Indian J. Agron., 1999, 44(3), 431-439.

ACKNOWLEDGEMENTS. We acknowledge the Division of Agronomy, ICAR-IARI, New Delhi for providing support for the study under the project 'Sustainable Integrated Farming Systems for Livelihood Security of Small and Marginal Farmers'.

\section{Isolation and characterization of indigenous nucleopolyhedrovirus infecting fall armyworm, Spodoptera frugiperda (J.E. Smith) (Lepidoptera: Noctuidae) in India}

\author{
G. Sivakumar ${ }^{1, *}$, M. Kannan ${ }^{2}$, S. Ramesh Babu ${ }^{3}$, \\ M. Mohan ${ }^{1}$, M. Sampath Kumar', \\ P. Raveendran', T. Venkatesan ${ }^{1}$, \\ R. Rangeshwaran ${ }^{1}$, Chandish R. Ballal ${ }^{1}$ and \\ P. Ram Kumar ${ }^{1}$ \\ ${ }^{1}$ ICAR-National Bureau of Agricultural Insect Resources, Hebbal, \\ Bengaluru 560 024, India \\ ${ }^{2}$ Department of Plant Protection, Horticultural College and Research \\ Institute, Periyakulam, Tamil Nadu Agricultural University, \\ Coimbatore 641 003, India \\ ${ }^{3}$ Agricultural Research Station, Borwat Farm, MPUAT, \\ Banswara 327 001, India
}

Fall armyworm (FAW), Spodoptera frugiperda (J.E. Smith) (Lepidoptera: Noctuidae) is an invasive insect pest of maize in India. Natural occurrence of nucleopolyhedrovirus (NPV) infection on $S$. frugiperda

\footnotetext{
*For correspondence. (e-mail: sivakumarg.nbaii@gmail.com)
}

larvae was recorded in 2018 during surveys conducted in maize fields in Chikkaballapura district of Karnataka, and Coimbatore and Tirupattur districts of Tamil Nadu. A strain of $S$. frugiperda nucleopolyhedrovirus (SpfrNPV NBAIR1) infecting $S$. frugiperda was isolated from the diseased larvae; morphological and biological characteristics were studied. Electron microscopic studies showed tetrahedral-shaped SpfrNPV occlusion bodies (OBs) of size $1.64 \mu \mathrm{m}$. Dose-mortality bioassays revealed that first, second and third instar larvae were equally susceptible $\left(\mathrm{LC}_{50}\right.$ 3.71-5.02 OBs $/ \mathrm{mm}^{2}$ ) to SpfrNPV infection. A PCR technique for detection of viral DNA in $S$. frugiperda NPV was developed by employing the polyhedrin gene (polh)-specific primers. The amplicon of $618 \mathrm{bp}$ was amplified, sequenced and NCBI GenBank accession number was obtained (MT422725). Blast analysis revealed that SpfrNPV conserved polh gene sequence matched $100 \%$ with the reference GenBank sequence (J04333) from the NCBI database which confirmed the identity of the SpfrNPV.

Keywords: Insect pests, maize, nucleopolyhedrovirus, Spodoptera frugiperda.

MAIZE is an important cereal crop cultivated in India after rice and wheat and is valued as food, feed, fodder and industrial raw material. India is the major maize producer and contributes $2 \%$ of the world's production ${ }^{1}$. The fall armyworm (FAW), Spodoptera frugiperda (J.E. Smith) (Lepidoptera: Noctuidae) has been reported as a devastating invasive insect pest of maize in America and Africa. Spodoptera frugiperda invaded India during May 2018 and then moved onto the neighbouring countries ${ }^{2}$. The pest is now reported in Yemen, Bangladesh, Sri Lanka, Thailand, Myanmar, China, Indonesia, Laos, Malaysia, Vietnam, Republic of Korea and Japan within a short span of time ${ }^{3}$. It has now established in India and causes extensive damage on maize throughout the country. The outbreak of $S$. frugiperda in India is of serious concern because of the favourable weather conditions and availability of maize throughout the year. Maximum incidence $(62.5 \%)$ of the pest was reported from Hassan district, Karnataka ${ }^{4}$. Advisories have been issued by the Government of India for its management through the use of biopesticides and chemical insecticides to avoid extensive damage on maize (http://ppqs.gov.in). Fall armyworm feeds on above-ground parts of maize, especially on the leaf whorl of young plants, which are up to 45 days old. Larvae are voracious feeders and can destroy the whole plant in a short time ${ }^{5}$. Studies in Africa indicated that infestation of $S$. frugiperda on maize exceeds $94 \%$ with damage levels ranging between $25 \%$ and $50 \%$ (ref. 6).

The development of multi-insecticide resistance and resistance against transgenic $B t$ maize makes $S$. frugiperda a challenging insect pest to manage using chemical insecticides and Bt toxins. Spodoptera frugiperda nucleopolyhedrovirus (SpfrNPV) belongs to the Baculoviridae 


\section{RESEARCH COMMUNICATIONS}
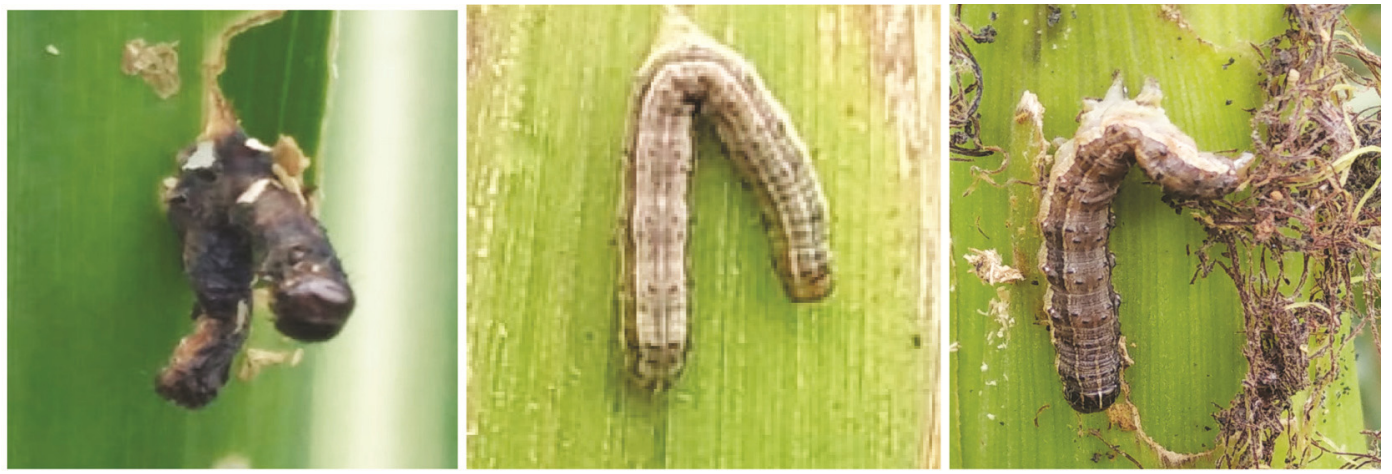

Figure 1. Diseased larvae of Spodoptera frugiperda showing characteristic viral infection symptoms.

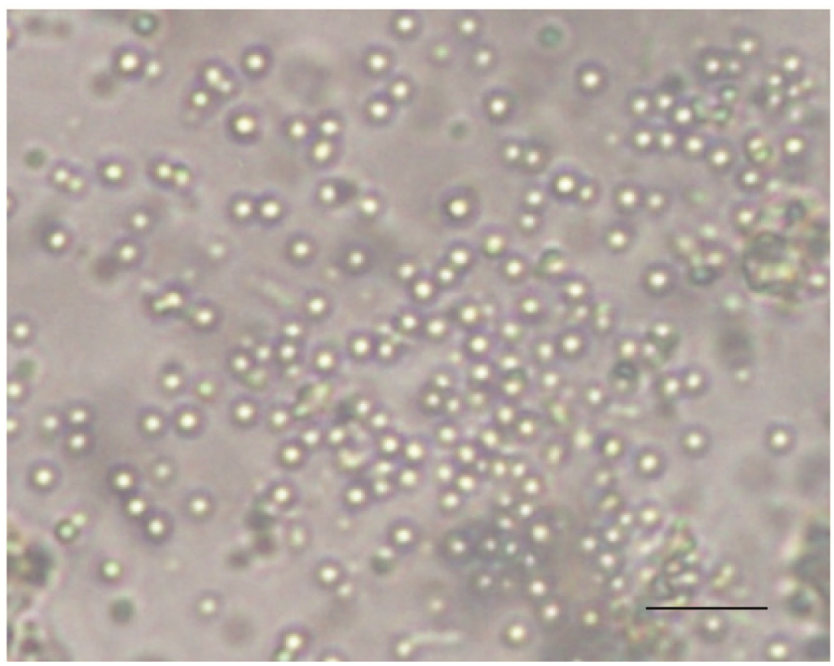

Figure 2. Light microscopy view of SpfrNPV occlusion bodies.

virus family and is recognized as an alternative method for managing insect pests effectively and in an environmentally sustainable manner. Baculoviruses are reported to be highly specific, virulent and safe to non-target organisms $^{7-9}$. Globally, different geographical isolates of SpfrNPV have been identified and used as potential ( $>80 \%$ efficacies) biological control agents against FAW $^{10-12}$. Several populations of SpfrNPV have been collected in North, Central and South America, Colombia and Brazil ${ }^{13-16}$. SpfrNPV is specific to FAW larvae, and $86.6-100 \%$ mortality of the larvae was recorded both in laboratory and field experiments ${ }^{17,18}$. During the course of the present study in maize fields, for recording the possible occurrence of FAW, few NPVinfected larvae were collected. Also, a novel virulent isolate of NPV associated with $S$. frugiperda has been characterized.

Surveys were conducted in maize fields of Chikkaballapura district in Karnataka and Coimbatore and Tirupattur districts in Tamil Nadu, and the diseased larvae of FAW showing viral infection symptoms were collected (Figure 1). Spodoptera frugiperda was further identified by amplification of mitochondrial cytochrome oxidase I gene (COI) marker. The nucleotide sequence was submitted to GenBank and the accession number was received (MK041922). The phase-contrast microscope visualization of discharged body fluids showed abundant spherical particles like occlusion bodies (OBs) of baculovirus, especially nucleopolyhedrovirus (Figure 2). The OBs of nucleopolyhedrovirus were extracted from the diseased larvae following the standard procedure ${ }^{19}$ and they were counted using a Neubauer's haemocytometer fixed on a phase-contrast compound light microscope at $10 \times$ and $40 \times$ magnification.

The morphological characterization of the extracted OBs was done using scanning electron microscope (SEM) and transmission electron microscope (TEM). Samples of purified OBs were processed using the standard protocol described by Martins et al. ${ }^{20}$. Further, the size of OBs and nucleocapsids were measured in the electron micrographs. The SpfrNPV solution was prepared and the $\mathrm{LC}_{50}$ values for first, second and third instar larvae were assessed using independent leaf disc bioassay method of Magholi et $a l^{21}$. The mortality of larvae was recorded on alternate days for six days post-treatment. The assays were carried out thrice and the pooled larval mortality data were subjected to probit analysis using the software POLO ${ }^{22}$ to calculate the $\mathrm{LC}_{50}$ values for larval instars.

The genomic DNA of NPV was isolated by the kit method (DNeasy Blood and Tissue Kit, Qiagen, Germany) and visualized using $0.8 \%$ of agarose gel. The conserved polyhedrin gene (polh) of NPV was targeted as template DNA. Species-specific primers ( $\mathrm{F}^{\prime}$ TCTAGGTTCGGTCATCAAGAAT; $\mathrm{R}^{\prime}$ TTGAACACGAGCGACAGTT) were designed based on the NCBI database and used for the detection of polh gene. PCR master mixture was used according to the protocol suggested by Thermo Scientific. The targeted marker was amplified by PCR reaction with 35 cycles of denaturation, annealing and extension. Amplified products were visualized using $1.2 \%$ agarose gel stained with ethidium bromide and compared with the GeneRuler 100 bp DNA ladder (Thermo Scientific). The eluted DNA template sequences were generated at 

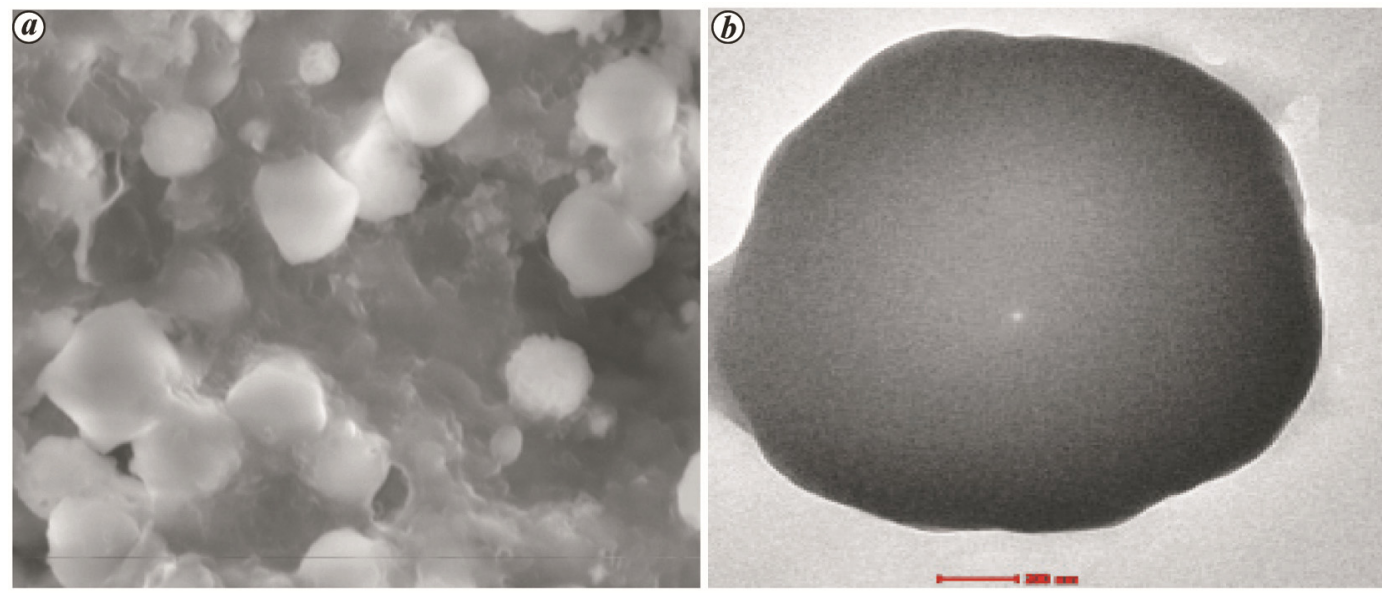

Figure 3. (a) Scanning and (b) transmission electron photomicrographs of tetrahedral occlusion bodies of SpfrNPV.

Table 1. Larval mortality in the different instars of Spodoptera frugiperda by SpfrNPV

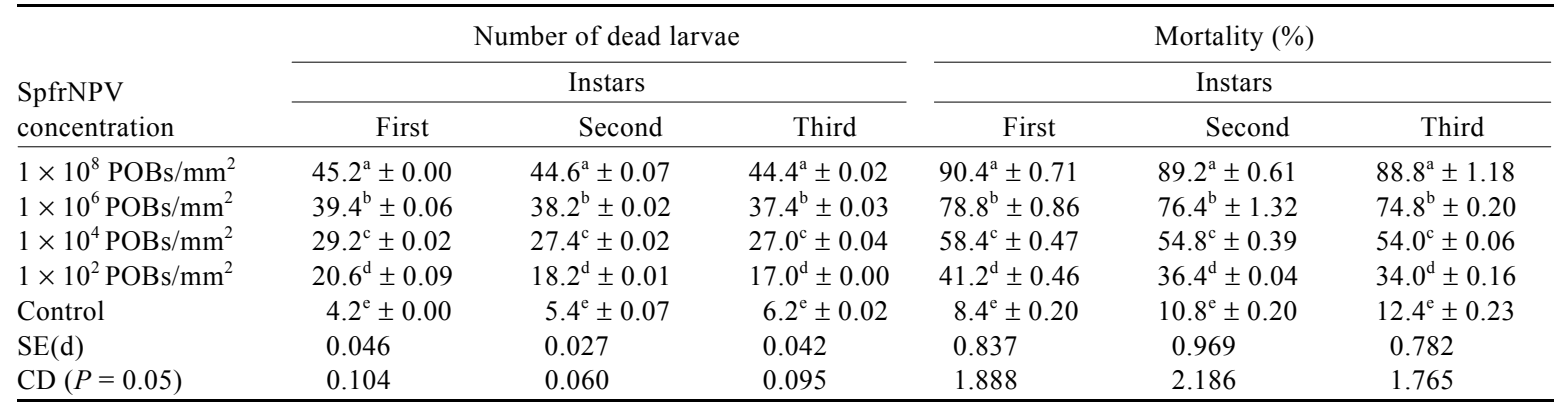

Table 2. Probit regression analysis of mortality data of SpfrNPV against S. frugiperda

\begin{tabular}{|c|c|c|c|c|c|c|c|}
\hline \multirow[b]{2}{*}{ Instars } & \multirow[b]{2}{*}{ Number of larvae used } & \multirow[b]{2}{*}{$\mathrm{LC}_{50}\left(\mathrm{POBs} / \mathrm{mm}^{2}\right)$} & \multirow[b]{2}{*}{ Slope \pm standard error } & \multicolumn{2}{|c|}{$\begin{array}{l}95 \% \text { Fiducial } \\
\text { limits }\end{array}$} & \multirow[b]{2}{*}{$\chi^{2}$} & \multirow[b]{2}{*}{ Degrees of freedom } \\
\hline & & & & Lower & Upper & & \\
\hline First & 50 & 3.71 & $1.12 \pm 0.12$ & 2.231 & 8.301 & 1.31 & 4 \\
\hline Second & 50 & 4.49 & $0.90 \pm 0.11$ & 2.832 & 11.205 & 7.20 & 4 \\
\hline Third & 50 & 5.02 & $1.0 \pm 0.12$ & 3.721 & 13.330 & 3.32 & 4 \\
\hline
\end{tabular}

Scigenome Laboratory, India. Confirmation of the identity of SpfrNPV was done based on nucleotide sequence homology and matching sequence similarity was done with the NCBI GenBank database using BLAST analysis. The nucleotide sequence was submitted to GenBank and accession number was assigned as MT422725.

Under SEM the OBs of SpfrNPV appeared tetrahedral in shape (Figure $3 a$ ). TEM showed tetrahedral-shaped OBs of size $1.64 \mu \mathrm{m}$ (Figure $3 \mathrm{~b}$ ). Laboratory experiments revealed that the virus concentration, i.e. $1 \times 10^{8} \mathrm{OBs} / \mathrm{mL}$ caused high percentage of larval mortality of $90.4,89.2$ and 88.8 to the first, second and third instar larvae of $S$. frugiperda respectively (Table 1). The study also showed that the mortality pattern of different larval instars was based on stage and concentration of SpfrNPV, and the calculated $\mathrm{LC}_{50}$ values for the first, second and third instar larvae of $S$. frugiperda were 3.71, 4.49 and $5.02 \mathrm{OBs} / \mathrm{mm}^{2}$ respectively (Table 2). Finally, the NPV-infected larvae dissolved and liquefied (Figure $4 a$ ). Pupal infection was also noticed in some of the replications at the end of the bioassay (Figure $4 b$ ). Observation of discharged liquid of infected pupae under light microscope also revealed the presence of OBs.

A PCR technique for detection of viral DNA in SpfrNPV was developed by employing the polh gene NPV specific primers. The amplicon of $618 \mathrm{bp}$ was amplified, and nucleotide sequence was submitted and accession number was obtained from GenBank (MT422725). Blast analysis revealed that the sequence of polh gene of SpfrNPV matched 100\% with the reference sequences in the NCBI database, and the identity of SpfrNPV was confirmed.

CURRENT SCIENCE, VOL. 119, NO. 5, 10 SEPTEMBER 2020 

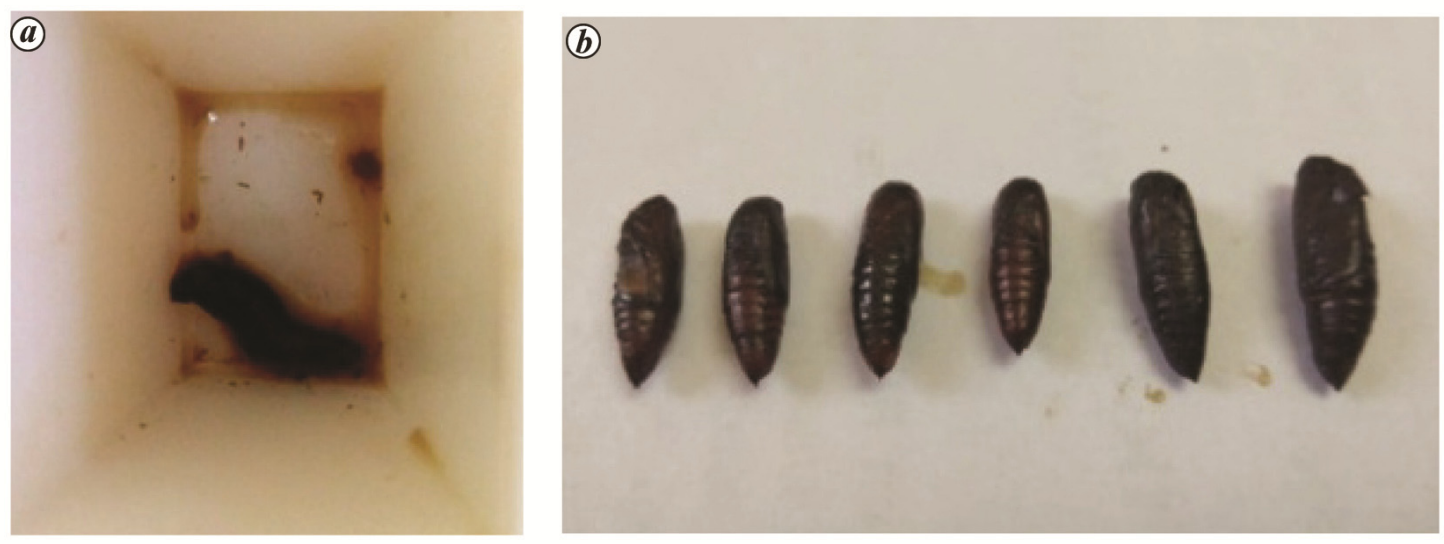

Figure 4. (a) Liquefaction of S. frugiperda larva and (b) liquid discharge of S. frugiperda pupae infected by SpfrNPV.

FAW is one of the most destructive insect pests of maize in India and its management has been done using different insecticides. However, studies have reported that continuous usage of insecticides leads to resistance development in S. frugiperda populations ${ }^{23-25}$. NPVs are important pathogens which infect and kill only the target insects. NPV is known for high epizootic levels and is naturally occurring, self-perpetuating, safe to natural enemies due to host specificity and eco-friendly. Hence, they could be potential biopesticides and an effective alternative to chemical insecticides in $S$. frugiperda management in India. Significant research has been done across the world on the natural occurrence and infectivity of NPVs in various lepidopteran insect pests. Raghunandan $e t a l .{ }^{26}$ reported the natural occurrence of SpfrNPV from Gujarat, while Firake and Behere ${ }^{27}$ reported it from Meghalaya. The present study has succeeded in isolating and characterising a NPV associated with FAW on maize. Electron microscopic studies revealed the tetrahedralshaped OBs of SpfrNPV. The tetrahedral and other shapes in OBs have been described earlier in several $\mathrm{NPVs}^{19,28-30}$. Since, polh gene is highly conserved, it serves as an excellent molecular diagnostic tool to characterize and identify the baculoviruses of lepidopteran insect pests ${ }^{31-33}$. There is a growing concern regarding the use of hazardous chemical insecticides for the management of FAW. Thus, management of maize FAW using SpfrNPV could be an effective, promising and ecofriendly alternative to hazardous synthetic insecticides.

1. Murdia, L. K., Wadhwani, R., Wadhawan, N., Bajpai, P. and Shekhawat, S., Maize utilization in India: An overview. Am. J. Food Nutr., 2016, 4(6), 169-176.

2. Sharanabasappa, D. et al., First report of the fall armyworm, Spodoptera frugiperda (J. E. Smith) (Lepidoptera, Noctuidae), an alien invasive pest on maize in India. Pest Manage. Hortic. Ecosys., 2018, 24, 23-29.

3. FAO, Regional workshop for Asia sustainable management of fall armyworm. Department of Agriculture Kunming City, Yunnan Province, China, 11-15 November 2019, p. 22.
4. Shylesha, A. N., Jalali, S. K., Gupta Ankita, Varshney Richa, Venkatesan, T. and Shetty, P., Studies on new invasive pest Spodoptera frugiperda (J. E. Smith) (Lepidoptera: Noctuidae) and its natural enemies. J. Biol. Control, 2018, 32(3); doi:10.18311/ $\mathrm{jbc} / 2018 / 217$.

5. Deole, S. and Paul, N., First report of fall armyworm, Spodoptera frugiperda (J.E. Smith), their nature of damage and biology on maize crop at Raipur, Chhattisgarh. J. Entomol. Zool. Stud., 2018, 6(6), 219-221.

6. Chimweta, M., Nyakudya, I. W., Jimu, L. and Mashingaidze, A. B., Fall armyworm (Spodoptera frugiperda (J.E. Smith)] damage in maize: management options for flood-recession cropping smallholder farmers. Int. J. Pest Manage., 2019; https://doi.org/ 10.1080/09670874.2019.1577514.

7. Moscardi, F., Assessment of the application of baculoviruses for control of Lepidoptera. Annu. Rev. Entomol., 1999, 44, 257-289.

8. Fuxa, J. R., Ecology of insect nucleopolyhedrovirus. Agric. Ecosyst. Environ., 2004, 103(1), 27-43.

9. Barrera, G., Simón, O., Villamizar, L., Williams, T. and Caballero, P., Spodoptera frugiperda multiple nucleopolyhedrovirus as a potential biological insecticide: genetic and phenotypic comparison of field isolates from Colombia. Biol. Control, 2011, 58, 113120.

10. Behle, R. W. and Popham, H. J., Laboratory and field evaluations of the efficacy of a fast-killing baculovirus isolate from Spodoptera frugiperda. J. Invertebr. Pathol., 2012, 109, 194-200.

11. Gómez, J., Guevara, J., Cuartas, P., Espinel, C. and Villamizar, L., Microencapsulated Spodoptera frugiperda nucleopolyhedrovirus: insecticidal activity and effect on arthropod populations in maize. Biocontrol. Sci. Technol., 2013, 23, 829-846.

12. Bentivenha, J. P. F., Juliana, G. R., Marcelo, F. L., Paula Marçon, H., Popham, J. R. and Celso Omoto, C., Baseline susceptibility of Spodoptera frugiperda (Lepidoptera: Noctuidae) to SfMNPV and evaluation of cross-resistance to major insecticides and $B t$ proteins. J. Econ. Entomol., 2019, 112, 91-98.

13. Berretta, M. F., Rios, M. L. and Sciocco-Cap, A., Characterization of a nuclear polyhedrosis virus of Spodoptera frugiperda from Argentina. J. Invertebr. Pathol., 1998, 71, 280-282.

14. Escribano, A., Williams, T., Goulson, D., Cave, R. D., Chapman, J. W. and Caballero, P., Selection of a nucleopolyhedrovirus for control of Spodoptera frugiperda (Lepidoptera: Noctuidae): structural, genetic, and biological comparison of four isolates from the Americas. J. Econ. Entomol., 1999, 92(5), 1079-1085.

15. Villamizar, L., Barrera, G., Cotes, A., Martínez, F. and Eudragit, S., Microparticles containing Spodoptera frugiperda nucleopolyehedrovirus: physicochemical characterization, photostability and in vitro virus release. J. Microencapsul., 2010, 27, 314-324. 


\section{RESEARCH COMMUNICATIONS}

16. Haase, S., Sciocco-Cap, A. and Romanowski, V., Baculovirus insecticides in Latin America: historical overview, current status and future perspectives. Viruses, 2018, 7, 2230-2267.

17. Valicente, F. H. and Costa, E. F., Control of fall armyworm, Spodoptera frugiperda (J.E. Smith) with Baculovirus Spodoptera through irrigation water. Ana. Soc. Entomol. Bras., 1995, 24, 6167.

18. Barrera, G., Gomez, J. and Villamizar, L., Efficacy of microencapsulated nucleopolyhedroviruses from Colombia as biological insecticides against Spodoptera frugiperda (Lepidoptera: Noctuidae). Acta Agron., 2017, 66, 267-274.

19. Hussain, B., Sivakumar, G., Kannan, M., War, A. R. and Ballal, C. R., First record of a nucleopolyhedrovirus infecting brown-tail moth larvae, Euproctis chrysorrhoea (L.) (Lepidoptera: Lymantriidae) in India. Egypt. J. Biol. Pest Control, 2019, 29, 11; doi.org/10.1186/s41938-019-0117-9.

20. Martins, T., Montiel, R., Medeiros, J., Oliveira, L. and Simões, N., Occurrence and characterization of a nucleopolyhedrovirus from Spodoptera littoralis (Lepidoptera: Noctuidae) isolated in the Azores. J. Invertebr. Pathol., 2005, 89, 185-192.

21. Magholi, Z., Abbasipour, H. and Marzban, R., Effects of Helicoverpa armigera nucleopolyhedrosis virus (HaNPV) on the larvae of the diamondback moth, Plutella xylostella (L.) (Lepidoptera: Plutellidae). Plant Prot. Sci., 2014, 50, 184-189.

22. Leora, Software and Polo-PC., User's Guide to Probit or Logit Analysis, LeOra Software, Berkeley, CA, USA, 1994

23. Carvalho, R. A., Omoto, C., Field, L. M., Williamson, M. S. and Bass, C., Investigating the molecular mechanisms of organophosphate and pyrethroid resistance in the fall armyworm, Spodoptera frugiperda. PLoS ONE, 2013, 8, 62268.

24. Nascimento, A. R. B., Farias, J. R., Bernardi, D., Horikoshi, R. J and Omoto, C., Genetic basis of Spodoptera frugiperda (Lepidoptera: Noctuidae) resistance to the chitin synthesis inhibitor lufenuron. Pest Manage. Sci., 2016, 72, 810-815.

25. Leonardo, M. B., Oderlei, B., Adriano, A. M., Maiquel, P. P., Thiago, T. S. and Jerson, V. C. G., Managing fall armyworm, Spodoptera frugiperda (Lepidoptera: Noctuidae), with Bt maize and insecticides in southern Brazil. Pest Manage. Sci., 2017, 73, 2569-2577.

26. Raghunandan, B. L., Patel, N. M., Dave, H. J. and Mehta, D. M., Natural occurrence of nucleopolyhedrovirus infecting fall armyworm, Spodoptera frugiperda (J. E. Smith) (Lepidoptera: Noctuidae) in Gujarat, India. J. Entomol. Zool. Stud., 2019, 7(2), 1040-1043.

27. Firake, D. M. and Behere, G. T., Natural mortality of invasive fall armyworm, Spodoptera frugiperda (J.E. Smith) (Lepidoptera: Noctuidae) in maize agroecosystems of northeast India. Biol. Control, 2020, 148, 104303.

28. Young, S. Y. and Yearian, W. C., Pathology of a nuclear polyhedrosis virus of Rachiplusia $n u$ in Rachiplusia ou (Lepidoptera: Noctuidae). J. Invertebr. Pathol., 1983, 42, 410-412.

29. Cheng, X. W. and Carner, G. R., Characterization of a new single nucleocapsid nucleopolyhedrovirus from Thysanoplusia orichalcea (Lepidoptera: Noctuidae) in Indonesia. J. Invertebr. Pathol. 2000, 75, 279-287.

30. Senthil Kumar, C. M., Jacob, T. K., Devasahayam, S. D., Silva, S., Jinsha, J. and Rajna, S., Occurrence and characterization of a tetrahedral nucleopolyhedrovirus from Spilarctia obliqua (Walker). J. Invertebr. Pathol., 2015, 132, 135-141.

31. Jehle, J. A., Lange, M., Wang, H., Hu, Z., Wang, Y. and Hauschild, R., Molecular identification and phylogenetic analysis of baculoviruses from Lepidoptera. Virology, 2006, 346, 180-193.

32. Sanjay, M., Bandi, Sivakumar, G. and Gandhi, Kiran, Baculoviruses: a lethal pathogens of lepidopteran caterpillars. J. Biol. Control, 2019, 33(4), 307-320.

33. Sivakumar, G. et al., Characterization and field evaluation of tetrahedral and triangular nucleopolyhedrovirus of Spilosoma obliqua (SpobNPV) strain NBAIR1 against Jute hairy caterpillar, Egypt. J. Biol. Pest Control, 2020, 30(82), 2-7.

ACKNOWLEDGEMENTS. We thank ICAR-National Bureau of Agricultural Insect Resources (ICAR-NBAIR), Bengaluru for providing the necessary facilities and Dr R. J. Rabindra, former Director, ICARNBAIR, Bengaluru, for morphological identification of SpfrNPV.

Received 27 May 2020; revised accepted 3 July 2020

doi: $10.18520 / \mathrm{cs} / \mathrm{v} 119 / \mathrm{i} 5 / 860-864$ 